Mila N. Krstajić Pajić ${ }^{1}$, Sanja I. Stevanović ${ }^{* 2}$, Vuk V. Radmilović ${ }^{3}$, Aleksandra Gavrilović-Wohlmuther ${ }^{4}$, Jelena $R$. Rogan $^{1}$, Velimir R. Radmilović, ${ }^{1,5}$, Vladislava M. Jovanović ${ }^{2}$

${ }^{1}$ University of Belgrade, Faculty of Technology and Metallurgy, Belgrade, Serbia, 'University of Belgrade, Department of Electrochemistry, ICTM, Belgrade, Serbia, ${ }^{3}$ University of Belgrade, Innovation Center, Faculty of Technology and Metallurgy, Belgrade, Serbia, ${ }^{4}$ CEST-Centre of Electrochemical Surface Technology $\mathrm{GmbH}$, Wiener Neustadt, Austria, ${ }^{5}$ Serbian Academy of Sciences and Arts, Belgrade, Serbia
Scientific paper

ISSN 0351-9465, E-ISSN 2466-2585

UDC:66.097.4/.8

doi: doi:10.5937/ZasMat1802159K

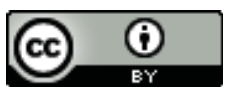

Zastita Materijala 59 (2) $159-166$ (2018)

\title{
PtAu catalyst with enhanced activity for formic acid oxidation
}

\begin{abstract}
PtAu systems are recognized as good catalysts for the oxidation of formic acid electrooxidation, which is investigated as a possible anodic reaction in low-temperature fuel cells. In this research, bimetallic PtAu nanoparticles, supported on high area carbon Vulcan XC-72R, were synthesized by water in oil microemulsion method. The precursor reduction process took place in a single microemulsion, simultaneously, in the presence of $35 \%$ of $\mathrm{HCl}$ in the water phase, as a capping agent. Electrochemical behavior of the PtAu/C catalyst was investigated at as prepared electrodes by cyclic voltammetry in $0.5 \mathrm{M} \mathrm{H}_{2} \mathrm{SO}_{4}$ as a supporting electrolyte, and also in the oxidation of adsorbed CO. The results were compared to the Pt/C catalyst prepared by the same synthesis procedure. PtAu/C catalyst powder was also characterized by X-Ray Diffraction (XRD), High Resolution Transmission Electron Microscopy (HRTEM) and Energy Dispersive X-Ray Spectroscopy (EDS). Average particle diameter, of $2 \mathrm{~nm}$, was calculated from XRD data, which is close to the value of $2.82 \mathrm{~nm}$ obtained from TEM images. Compared to identically synthesized Pt nanoparticles, the bimetallic ones are significantly smaller. EDS maps of PtAu/C sample confirm the presence of both elements, and indicate a very fine distribution of Au in the sample. Elemental composition of about 20\% Au and $80 \%$ Pt was also determined from these maps. Prepared catalyst was tested for formic acid electro-oxidation in terms of its activity and stability over the long term cycling. The voltammograms recorded indicate the change of reaction mechanism and better utilization of the catalyst surface in comparison to Pt/C.

Keywords: PtAu nanoparticles, microemulsion method, formic acid electro-oxidation.
\end{abstract}

\section{INTRODUCTION}

Direct formic acid fuel cells (DFAFCs) have attracted worldwide attention because they are promising low-cost and efficient power sources for portable electronic devices. Thanks to their high energy density $(2086 \mathrm{Wh} / \mathrm{L})$, high theoretical open circuit voltage $(1.45 \mathrm{~V})$, fast oxidation kinetics and the non-toxic nature of formic acid, DFAFCs have a lot of advantages over the direct methanol fuel cells (DMFCs) and $\mathrm{H}_{2}$-PEM fuel cells [1]. It is well known that the application of hydrogen fuel cells is limited by the potential dangers in storing and distributing hydrogen while DMFCs exhibit high methanol crossover through

Corresponding author: Sanja I. Stevanović

E-mail: sanjat@tmf.bg.ac.rs

Paper received: 26. 04. 2018.

Paper accepted: 14. 05. 2018.

Paper is available on the website: www.idk.org.rs/journal
Nafion ${ }^{\circledR}$ membrane (leading to cathode catalyst poisoning and a drop in fuel cell efficiency), high toxicity and slow methanol electro-oxidation kinetics. Formic acid is less likely to undergo crossover flux through Nafion (diffusion through membrane without a reaction) than methanol due to the repulsion forces between $\mathrm{HCOO}^{-}$ion and sulfuric group at the surface of the membrane, which allows the use of highly concentrated formic acid solutions and thinner membranes [2].

The oxidation of formic acid on Pt follows a dual pathway [3]. Direct oxidation pathway involves the dehydrogenation of the formic acid molecule and $\mathrm{CO}_{2}$ accumulation:

$$
\mathrm{HCOOH} \rightarrow \mathrm{CO}_{2}+2 \mathrm{H}^{+}+2 e^{-}
$$

In the indirect pathway, through the formic acid dehydration, strongly adsorbed carbon monoxide (CO) is formed as a reaction intermediate: 
$\mathrm{HCOOH} \rightarrow \mathrm{CO}_{a d s}+\mathrm{H}_{2} \mathrm{O} \rightarrow \mathrm{CO}_{2}+2 \mathrm{H}^{+}+2 \mathrm{e}^{-}$

Although the direct pathway is desirable in DFAFCs because the dehydrogenation of formic acid leads to reduction of catalyst poisoning and the enhancement of cell efficiency, the oxidation of formic acid on $\mathrm{Pt}$ catalyst surface dominantly proceeds through the indirect pathway. The amount of $\mathrm{CO}_{\text {ads }}$ produced in the indirect pathway blocks the reaction sites and therefore remarkably reduces electrocatalytic activity. In order to diminish surface poisoning caused by $\mathrm{CO}_{\text {ads }}$, bimetallic surfaces are synthesized in which the second metal (oxophilic metal) provides oxygen species at lower potentials and therefore facilitates the oxidative removal of $\mathrm{CO}_{\text {ads }}$ [4]. This effect is known as the bi-functional effect. Beside this effect, the addition of a second metal can lead to the modification of the electronic structure of $\mathrm{Pt}$ and in turn, the energy adsorption of $\mathrm{CO}_{\mathrm{ads}}$, which can increase the tendency of $\mathrm{Pt}$ to dehydrogenate the formic acid molecule. This is recognized as the electronic effect. Another very effective way to enhance the electro-oxidation kinetics of formic acid on Pt is the ensemble effect, which is based on the fact that, in order for $\mathrm{CO}$ to form by dissociative adsorption of formic acid, it is necessary to have at least two ensemble connected Pt sites, while for the direct FAO, this is not the case. If the Pt sites are isolated by the second metal (often named as surface modifier) indirect pathway in the electro-oxidation reaction can be suppressed and the direct pathway favored.

In an effort to replace Pt with a less precious metal and, at the same time improve catalytic activity, during the past decade several bimetallic $\mathrm{Pt}-\mathrm{M}(\mathrm{M}=\mathrm{Bi}, \mathrm{Ru}, \mathrm{Sn}, \mathrm{Pd}, \mathrm{Pb}$, and $\mathrm{Au}$ ) catalysts have been extensively investigated [5-10] with PtAu catalysts being one of the most promising systems in terms of the catalytic activity and stability [11-15]. Many forms of PtAu catalysts have been synthetized for the formic acid electrooxidation reaction with the goal of tuning the composition, morphology and structure in order to acquire enhanced electrocatalytic activity and in turn good performance of fuel cells. In order for these catalysts to be considered as high performing, certain property criteria must be met: high density active sites, high corrosion and chemical resistances, high electrical conductivity and optimal surface adsorption [16]. Therefore, the search for correlations between catalyst reactivity and corresponding surface properties has become a scientific imperative.
One of the promising synthesis methods for $\mathrm{Pt}$ catalysts in the recent years has been the water-inoil microemulsion method in which shapecontrolled nanoparticles can be achieved by incorporation of a capping agent into the water phase of the microemulsion (which consists of a precursor solution). It turned out that $\mathrm{HCl}$ is a promising capping and stabilizing agent for obtaining nanocatalysts with characteristics of single crystals and preferential surface facet orientation $[17,18]$. It is well known that formic acid electro-oxidation at lower potentials is almost inhibited on $\mathrm{Pt}(100)$ and $\mathrm{Pt}(110)$ surfaces of single crystals. In the case of $\mathrm{Pt}(111)$, the least poisoned single crystal surfaces, FAO goes through direct path i.e. a bell shaped single peak.

The aim of the present work was to obtain PtAu nanoparticles, synthesized analogous to previously reported shape-controlled Pt nanoparticles [19], with preferred crystallographic orientation of the catalyst surface, as to further improve the catalytic performance of $\mathrm{Pt}$.

This paper is dedicated to the memory of Prof. dr Nedeljko Krstajić, who made a significant contribution to the field of electrocatalysis.

\section{EXPERIMENTAL}

\subsection{Preparation of the catalyst}

The PtAu catalyst was synthesized by the water-in-oil microemulsion method, analogous to our previously reported synthesis of shape controlled Pt/C catalyst [19]. PtAu nanoparticles were obtained by simultaneous reduction from a single microemulsion, where the water phase consisted of $0.05 \mathrm{M}$ precursor solution $\left(\mathrm{H}_{2} \mathrm{PtCl}_{6}\right.$ and $\mathrm{HAuCl}_{4}$ ) in $35 \% \mathrm{HCl}$, used as a capping agent. The solution was subsequently mixed with polyethilenglycol-dodecilether $\left(B R I J^{\circledR}\right)$, used as a surfactant as well as n-heptane, as the non-polar phase, by a magnetic stirrer for 40 minutes. When the microemulsion was formed, $\mathrm{NaBH}_{4}$ reducing agent was added as a solid, in great excess, in order to produce nanoparticles, very small in size. The reduction reaction took place within a few minutes, after which Vulcan XC-72R (carbon support) was added in the microemulsion system and the whole mixture was stirred for several hours. Acetone was added in order to destabilize the microemulsion and induce precipitation. Subsequent to the phase separation, the precipitate was washed with $0.02 \mathrm{M}$ of $\mathrm{NH}_{4} \mathrm{OH}$ solution in ultra-pure water (Millipore, $18 \mathrm{M} \Omega$ ) on a 
membrane filter, using a vacuum pump, and dried in $\mathrm{N}_{2}$ atmosphere at $160^{\circ} \mathrm{C}$ for 3 hours. The synthesized catalyst was characterized by electrochemical and physical methods, and the results were compared to the ones obtained for a $\mathrm{Pt} / \mathrm{C}$ catalyst synthesized by the same method with the same amount of capping agent $(35 \% \mathrm{HCl})$.

\subsection{Characterization of the catalyst}

Microstructural characterization of the catalyst was performed by X-ray diffraction (XRD) and transmission electron microscopy (TEM) in tandem with energy dispersive X-ray spectroscopy. XRD characterization of the catalyst was performed on an X-Pert powder diffractometer (PANalytical, Netherlands) using CuKa radiation in BraggBrentano geometry at $40 \mathrm{kV}$ and $30 \mathrm{~mA}$. The measurements were conducted in a step scan mode in $0.05^{\circ}(2 \ominus)$ intervals with a measuring time of $30 \mathrm{~s} / \mathrm{step}$. The TOPAS V3 general profile and structure analysis software for powder diffraction data was used for the Rietveld refinement procedure [20]. Electron microscopy analysis of the $\mathrm{PtAu} / \mathrm{C}$ catalyst was performed on a FEI Thermo Scientific $^{\text {TM }}$ TITAN $^{3}$ Themis $^{\text {TM }}$ 60-300 double aberration corrected TEM. For TEM investigations samples were drop cast onto Holey carbon grids and investigated at $200 \mathrm{kV}$ operating voltage by high resolution transmission electron microscopy (HRTEM) and scanning transmission electron microscopy (STEM).

All electrochemical experiments were performed at room temperature in a three-electrodecompartment electrochemical cell with a Pt wire as the counter electrode and a bridged saturated calomel electrode (SCE) as the reference electrode. All potential values are given versus SCE. The working electrode was a thin layer of Nafionimpregnated PtAu/C catalyst applied on a freshly polished glassy carbon electrode. The thin layer was obtained from a suspension $(2 \mathrm{mg}$ of the catalyst, $1 \mathrm{ml}$ water and $50 \mu \mathrm{l}$ of $5 \%$ aqueous Nafion solution) prepared in an ultrasonic bath, placed on the electrode and dried at room temperature.

The $\mathrm{PtAu} / \mathrm{C}$ and $\mathrm{Pt} / \mathrm{C}$ catalysts were electrochemically characterized in a $0.5 \mathrm{M} \mathrm{H}_{2} \mathrm{SO}_{4}$ solution as supporting electrolyte in the potential range from $-0.2 \mathrm{~V}$ to $1.2 \mathrm{~V}$ versus SCE for the $\mathrm{PtAu} / \mathrm{C}$ and from $-0.2 \mathrm{~V}$ to $0.55 \mathrm{~V}$ versus SCE for the $\mathrm{Pt} / \mathrm{C}$ catalyst.

The electrocatalytic activity of the PtAu/C catalyst was studied in a solution containing $0.5 \mathrm{M}$ of $\mathrm{H}_{2} \mathrm{SO}_{4}$ and $0.5 \mathrm{M}$ of $\mathrm{HCOOH}$. The latter acid was added to the supporting electrolyte solution while holding the electrode potential at $-0.2 \mathrm{~V}$. The potential was then cycled up to $0.9 \mathrm{~V}$ at a sweep rate of $50 \mathrm{mV} / \mathrm{s}$. Long-term stability of the catalyst was tested for FAO during 100 cycles in the same potential range.

CO stripping voltammograms were used for the investigation of CO-poisoning resistance of the catalyst. For the $\mathrm{CO}$ stripping measurements, $\mathrm{CO}$ was adsorbed at the electrode surface from $\mathrm{CO}$ saturated $0.5 \mathrm{M} \mathrm{H}_{2} \mathrm{SO}_{4}$ solution while keeping the electrode potential at $-0.2 \mathrm{~V}$ for $15 \mathrm{~min}$. Subsequently, the electrode was transferred into the cell containing only $0.5 \mathrm{M} \mathrm{H} \mathrm{H}_{2} \mathrm{SO}_{4}$ and the adsorbed $\mathrm{CO}$ was electrochemically oxidized at a sweep rate of $50 \mathrm{mV} / \mathrm{s}$.

The real surface area of the catalyst was determined from the $\mathrm{Pt}$-oxide reduction peak using a charge of $440 \mathrm{C} / \mathrm{cm}^{2}$ for a Pt-oxide monolayer [21].

Thermogravimetric analysis (TGA) confirmed lower content of metal than $10 \mathrm{wt} \%$.

All solutions were prepared from Merck p.a. grade reagents with high purity water (Millipore, 18 $\mathrm{M} \Omega \mathrm{cm}$ resistivity). The electrolytes were purged with purified nitrogen prior to each experiment. AUTOLAB potentiostat/galvanostat PGStat 128N (MetrohmAutolab B.V., The Netherlands) was used in electrochemical experiments.

\section{RESULTS AND DISCUSSION}

\subsection{Physicochemical characterization of the PtAu/C catalyst}

The XRD patterns of the carbon-supported $\mathrm{PtAu}$ and $\mathrm{Pt}$ samples (Fig. 1) show main characteristic peaks for an fcc structure, as expected. The diffraction peak at $\sim 25^{\circ}$ originates from hexagonal, graphite like structure of Vulcan support. The diffraction peaks, of PtAu/C catalyst, noted in Fig. 1, can be attributed to the presence of three phases: Pt metallic, Au metallic, and $\mathrm{PtAu}_{3}$ alloy. Due to the very small difference in lattice parameter, it is not possible to distinguish between the peaks of Pt and Au in the XRD spectra. Lattice parameter and average particle size for the $\mathrm{Pt}$ nanoparticles were calculated, in our previous work, to be $3.928 \AA$ and $\sim 2 \mathrm{~nm}$, respectively [19]. From the Gaussian distribution of the PtAu/C $2 \theta$ angle for 311 peak in the XRD spectra along with $\lambda(\mathrm{CuK \alpha})=0.15418 \mathrm{~nm}$ and Bragg's law $\lambda=2 \mathrm{~d} \sin \theta$ and, the lattice parameter of PtAu nanoparticles was calculated to be $3.91956 \AA$. 


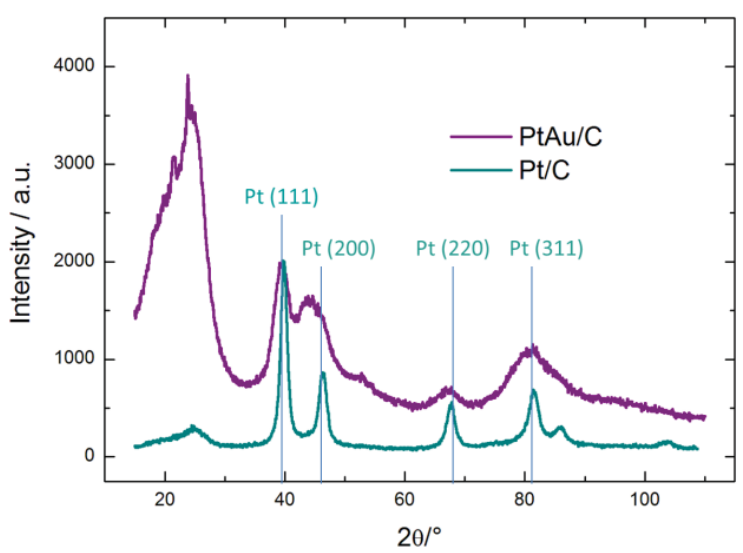

Figure 1. XRD patterns of PtAu/C and Pt/C catalysts

Slika 1. XRD dijagrami za PtAu/C i Pt/C katalizatore

From energy dispersive X-ray spectroscopy (EDS) elemental maps, obtained from scanning transmission electron micrographs (STEM) in high angle annular dark field (HAADF) mode, as the one seen in Fig. 2, the mean value of the elemental composition of $\mathrm{Pt}$ and $\mathrm{Au}$ was calculated to be 78.51 at $\%$ for $\mathrm{Pt}$ and 21.49 at\% for Au. It should be noted that these results are mean values of calculated at\% of $\mathrm{Pt}$ and $\mathrm{Au}$ from numerous EDS maps and present only a rough estimate of the structure composition. However, the effect of possible non-uniform distribution of $\mathrm{Pt}$ and $\mathrm{Au}$ can affect the mean composition value.
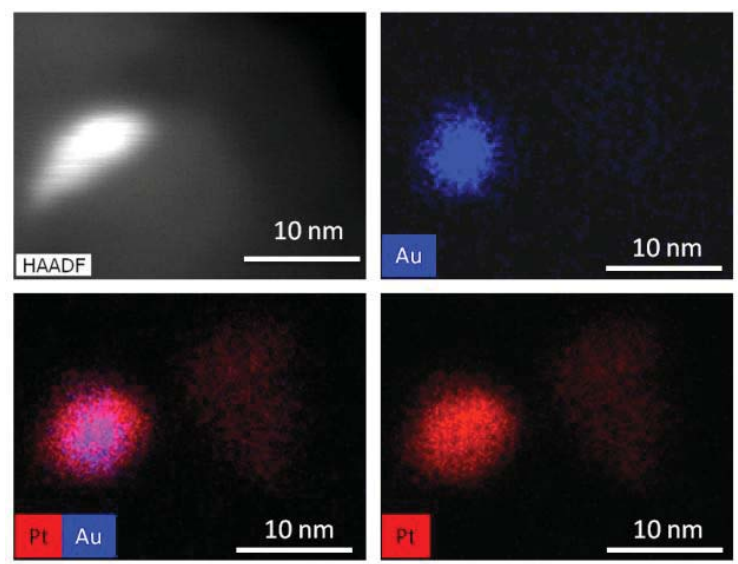

Figure 2. STEM HAADF image of a PtAu nanoparticle on carbon support and corresponding EDS maps noting the elemental distribution of $P t$ and $\mathrm{Au}$

Slika 2. STEM HAADF slika PtAu nanočestice na ugljeničnoj podlozi i pripadajuće EDS mape koje ukazuju na raspodelu elemenata Pt i Au
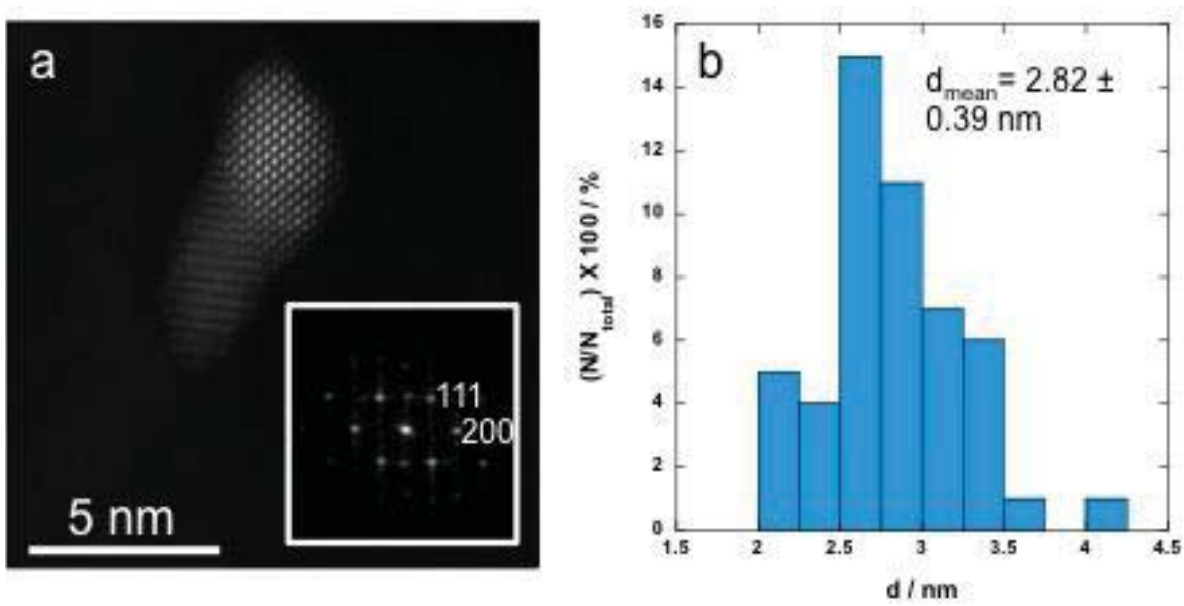

Figure 3. a) High resolution transmission electron micrograph (HRTEM) along with FFT (in inset) with noted 111 and 200 reflections and b) particle size distribution of PtAu/C catalyst with the calculated mean particle size of $2.82 \pm 0.39 \mathrm{~nm}$

Slika 3. a) Visokorezoluciona transmisiona elektronska mikrofotografija (HRTEM) zajedno sa Brzom

Furijeovom Transformacijom, FFT, (predstavljena u umetku slike) gde se vide 111 i 200 refleksije,

b) histogram raspodele veličine čestica PtAu/c katalizatora sa izračunatom srednjom vrednošću od $2.82 \pm 0.39 \mathrm{~nm}$

From the HRTEM image (Fig. 3a) it can be clearly seen that the PtAu nanoparticles have a face-centered cubic (fcc) type structure, with an orientation close to $\{110\}$. Fast Fourier Transforms (FFT) of particles (inset in Fig. 3a) reveal the presence of $\{111\}$ and $\{200\}$ type planes. Mean 
particle size, by analysis of TEM images, was calculated to be $2.82 \pm 1.4 \mathrm{~nm}$ (Fig. $3 \mathrm{~b}$ ). This value is significantly smaller than $3.7 \pm 1.8 \mathrm{~nm}$, the particle size of $\mathrm{Pt} / \mathrm{C}$ catalyst synthesized in the same manner [19].

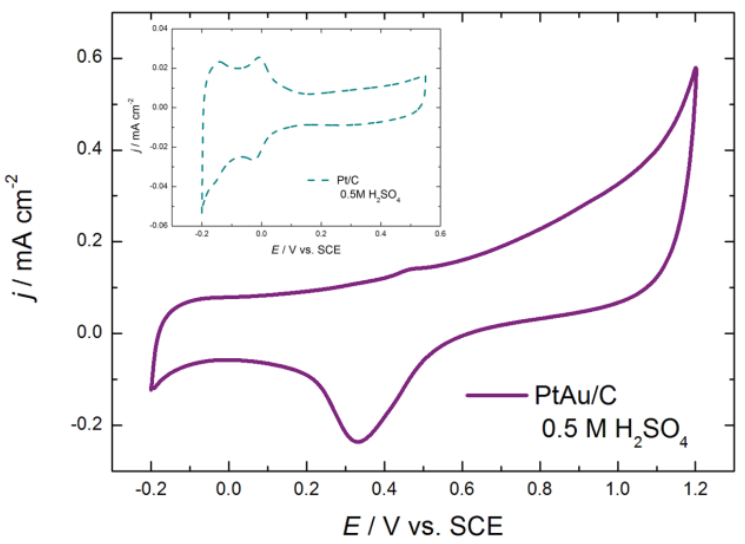

Figure 4. Cyclic voltammograms of as-prepared $P t A u / C$ and Pt/C (given in inset) catalysts in $0.5 \mathrm{M}$ $\mathrm{H}_{2} \mathrm{SO}_{4}(\mathrm{~V}=50 \mathrm{mV} / \mathrm{s})$

Slika 4. Ciklični voltamogrami za pripremljene

PtAu/C i Pt/C (dat u umetku) katalizatore, $u$ polaznom stanju, u $0.5 \mathrm{M} \mathrm{H}_{2} \mathrm{SO}_{4}(\mathrm{~V}=50 \mathrm{mV} / \mathrm{s})$

\subsection{Electrochemical characterization of the PtAu/C catalyst}

The initial scan of as-prepared PtAu/C, obtained without any electrochemical treatment is shown in Fig. 4. The characteristic peaks for hydrogen adsorbtion/desorbtion are not registered for $\mathrm{PtAu} / \mathrm{C}$, while the typical hydrogen adsorbtion/desorbtion region, with characteristic peaks for $\{110\}$ planes, (100) steps and terraces as well as a well-defined double-layer region are clearly visible for the $\mathrm{Pt} / \mathrm{C}$ catalyst (Fig. 4 inset) [19]. Furthermore, the onset of oxide formation and potential of oxide reduction at PtAu/C (Fig. 4) are shifted for $\sim 100 \mathrm{mV}$ to more positive potentials and for $\sim 70 \mathrm{mV}$ to lower values, respectively, in comparison to $\mathrm{Pt} / \mathrm{C}$ catalyst prepared under the same conditions [19] which this is in good agreement with the data from literature [23]. The characteristic peaks for Au are not clearly defined which should indicate that $\mathrm{Au}$ is present on the surface in very small quantities [24,25]. This is can be confirmed with some results obtained by STEM/EDS analysis, which show occasional Au presence on the surface Pt particles and/or clusters.

The catalyst tolerance for $\mathrm{CO}$ of the asprepared electrodes was evaluated from COstripping measurements (Fig. 5). Observing the curve presented in Fig. 5 it is evident that the oxidation of $\mathrm{CO}$ on PtAu/C surface commences some $150 \mathrm{mV}$ earlier than on $\mathrm{Pt} / \mathrm{C}$ (inset in Fig. 5) [19] and proceeds through a sharp peak with a maximum at $\sim 0.65 \mathrm{~V}$. The shift of this maximum peak potential of $\mathrm{PtAu} / \mathrm{C}$ compared to $\mathrm{Pt} / \mathrm{C}$ can lead to the conclusion that $\mathrm{CO}$ molecules are more strongly adsorbed on PtAu/C catalyst. Similar behavior was reported literature and was based on the hypothesis that $\mathrm{CO}_{\text {ads }}$ oxidation potential is more positive when the $\mathrm{Au}$ is present at the $\mathrm{Pt}$ surface and increases as more $\mathrm{Pt}$ atoms are in direct contact with $\mathrm{Au}[14,23,26]$. It is very important to point out that the oxidation of adsorbed $\mathrm{CO}$ is controlled by the amount of defects i.e. surfaces with fewer defects show a COstripping peak at higher potentials [22].

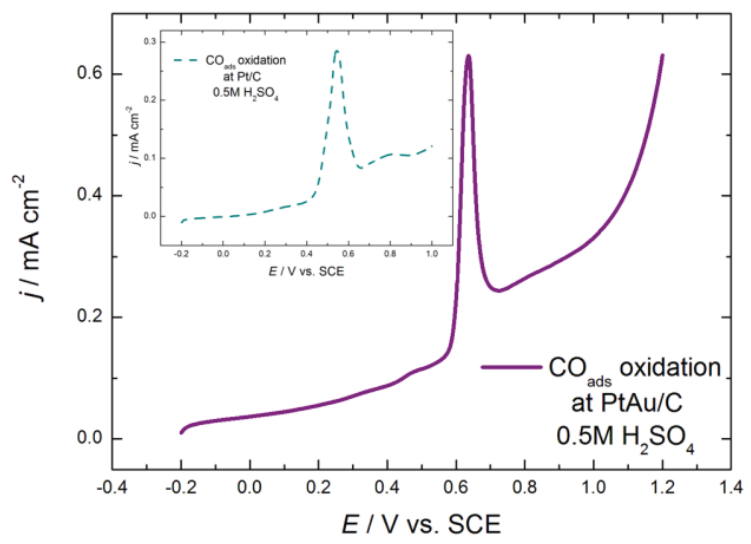

Figure 5. $\mathrm{CO}_{a d s}$ stripping curves for as-prepared PtAu/C and Pt/C (given in inset) catalysts in $0.5 \mathrm{M}$ $\mathrm{H}_{2} \mathrm{SO}_{4}(\mathrm{~V}=50 \mathrm{mV} / \mathrm{s})$

Slika 5. Oksidacija adsorbovanog $\mathrm{CO}_{a d s}$ za PtAu/C i Pt/C katalizatore u polaznom stanju (data $u$ umetku) katalizatore u $0.5 \mathrm{M} \mathrm{H}_{2} \mathrm{SO}_{4}(v=50 \mathrm{mV} / \mathrm{s})$

The results presented clearly show that the $\mathrm{CO}_{\text {ads }}$ oxidation on PtAu/C catalyst at more positive potential than $\mathrm{Pt} / \mathrm{C}$ catalyst is due to highly dispersed Au, occasionally on the surface of PtAu particles and fewer defects on Pt domains.

\subsubsection{Electrocatalytic activity of the catalyst}

Formic acid oxidation (FAO) was examined for as-prepared $\mathrm{PtAu} / \mathrm{C}$ catalyst and compared to the results obtained for the previously synthesized Pt/C catalyst [19]. The initial forward scans are presented in Fig. 6 and according to the shape of the polarization curve for the $\mathrm{Pt} / \mathrm{C}$, the reaction proceeds through a characteristic well-defined shape for FAO on $\mathrm{Pt}$ with two peaks in forward direction. Such a shape of the polarization curve reveals a dual-path mechanism, with a larger contribution of the indirect pathway (peak present 
at higher potential) [19]. The potentiodynamic curve for FAO on PtAu/C is completely different, indicating a change in the reaction mechanism. The reaction starts $\sim 0.1 \mathrm{~V}$ earlier and even though it proceeds through a dual-path mechanism as well, the contribution of the dehydrogenation step (direct path) is much larger than the contribution of the dehydration step (indirect path) in the reaction (Fig. 6). The dominant of dehydrogenation step in FAO mechanism indicates a lower poisoning rate of $\mathrm{PtAu} / \mathrm{C}$ catalyst, compared to $\mathrm{Pt} / \mathrm{C}$, which is expected for a bimetallic surface [27].

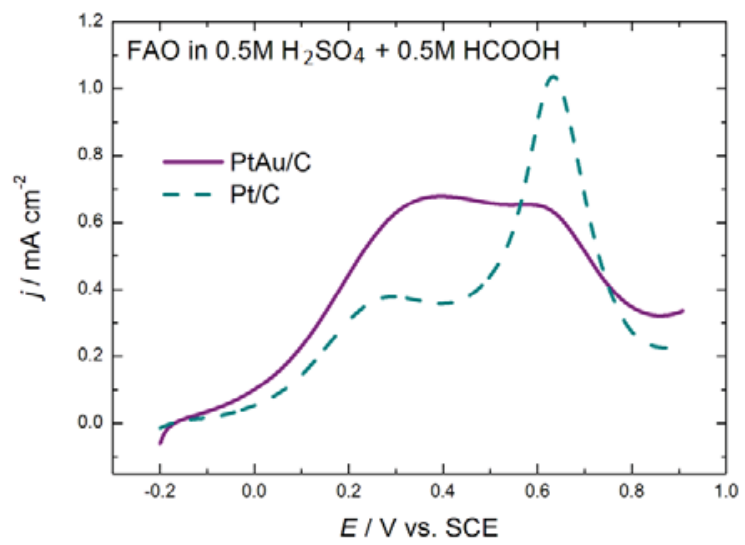

Figure 6. Potentiodynamic curves for the oxidation of 0.5M HCOOH on as-prepared PtAu/C and Pt/C catalysts ( $v=50 \mathrm{mV} / \mathrm{s})$

Slika 6. Potenciodinamičke krive za oksidaciju 0.5M HCOOH na PtAu/C i Pt/C katalizatorima $u$ polaznom stanju ( $V=50 \mathrm{mV} / \mathrm{s})$

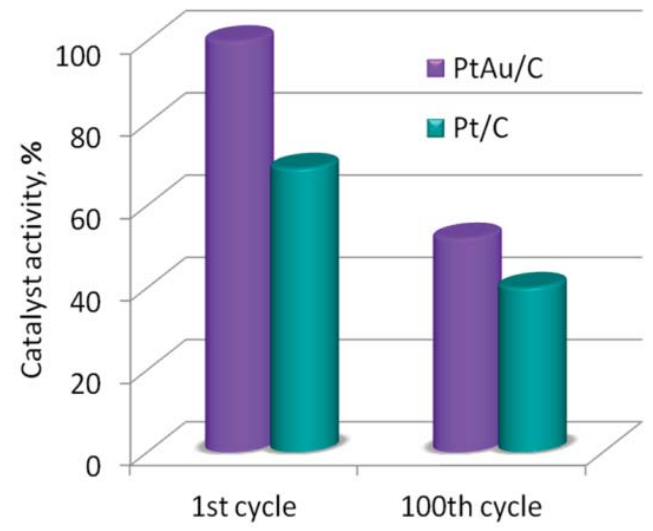

Figure 7. Long-term stability of as-prepared PtAu/C and Pt/C catalysts versus the number of scans during FAO (current values taken at $0.2 \mathrm{~V}$; $v=50 \mathrm{mV} / \mathrm{s}$ )

Slika 7. Test dugoročne stabilnosti za PtAu/C i Pt/C katalizatore, u polaznom stanju, izražene u odnosu na broj ciklusa tokom oksidacije mravlje kiseline (vrednosti struje su očitane na potencijalu od $0.2 \mathrm{~V}$; $v=50 \mathrm{mV} / \mathrm{s}$ )
Catalyst stability was tested over 100 cycles in the potential range from $-0.2 \mathrm{~V}$ to $0.9 \mathrm{~V} \mathrm{vs}$. SCE, and compared to the results obtained for the $\mathrm{Pt} / \mathrm{C}$ catalyst (Fig. 7). The current density values at the potential of $0.2 \mathrm{~V}$ are presented as a percentage of the highest value which was recorded for PtAu/C in the first cycle, so the decline in the catalyst activity would be notable. It is evident that the bimetallic catalyst shows, not only higher initial activity, but also remains more active even after long term cycling, indicating superior stability compared to $\mathrm{Pt} / \mathrm{C}$ catalyst.

\section{CONCLUSION}

A carbon supported PtAu (PtAu/C) nanocatalyst was successfully synthesized by a water-in-oil microemulsion method, with $\mathrm{NaBH}_{4}$ and $\mathrm{HCl}$ as reducing and capping agents, respectively. Microstructural characterization including XRD and TEM in tandem with EDS revealed that synthetized particles are small in size ( $2.8 \mathrm{~nm}$ in diameter), composed of 78.51 at\% $\mathrm{Pt}$ and 21.49 at\% $\mathrm{Au}$ and uniformly distributed on carbon support, an advantage inherent from this type of synthesis. The electrocatalytic activity and stability were tested for FAO and improved activity of PtAu/C catalyst in comparison to $\mathrm{Pt} / \mathrm{C}$ catalyst is manifested through the favoring of the direct path. The domination of dehydrogenation in FAO mechanism indicates a lower poisoning rate of $\mathrm{PtAu} / \mathrm{C}$ catalyst as a consequence of the presence of small $\mathrm{Pt}$ ensembles, which are in direct contact with Au.

\section{Acknowledgements}

This work was financially supported by the Ministry of Education, Science and Technological Development, Republic of Serbia, Contract No. 172060, 172054, and III45019. VVR and VRR acknowledge the Center for Nanoanalysis and Electron Microscopy (CENEM), Friedrich-Alexander-University of Erlangen-Nürnberg, Germany, where electron microscopy characterization has been performed. VRR acknowledges support by Serbian Academy of Sciences and Arts under contract \#F-141.

\section{REFERENCES}

[1] Y.Zhu, S.Y.Ha, R.I.Masel (2004) High power density direct formic acid fuel cells, J.Power Sources,130(12), 8-14.

[2] Y.W. Rhee, S.Y. Ha, R.I. Masel (2003) Crossover of formic acid through Nafion $®$ membranes, J. Power Sources, 117, 35-38. 
[3] S.Gilman (1964) The Mechanism of Electrochemical Oxidation of Carbon Monoxide and Methanol on Platinum. II. The "Reactant-Pair" Mechanism for Electrochemical Oxidation of Carbon Monoxide and Methanol, J. Phys. Chem., 68, 70-80.

[4] N.M.Markovic, H.A.Gasteiger, P.N.Ross, X.Jiang, I.Villegas, M.J.Weaver (1995) Electro-oxidation mechanisms of methanol and formic acid on Pt-Ru alloy surfaces, Electrochim. Acta, 40, 91-98.

[5] C. Rice, S. Ha, R.I. Masel, A. Wieckowski (2003) Catalysts for direct formic acid fuel cells, J. Power Sources, 115 , 229-235.

[6] X.Yu, P.G.Pickup (2011) Carbon supported PtBi catalzst for formic acid fuel cells, Electrochim. Acta, $56,4037-4043$.

[7] J.Choi, K.Jeong, Y.Dong, J.Han, T.Limb, J.Lee, Y. Sung (2006) Electro-oxidation of methanol and formic acid on PtRu and PtAu for direct liquid fuel cells, J. Power Sources, 163, 71-75.

[8] L. Zheng, L.Xiong, Q.Liu, K.Han, Y.Li, K.Tao, L. Niu, S.Yang, J.Xia (2011) Enhanced electrocatalytic activity for the oxidation of liquid fuels on PtSn nanoparticles, Electrochim. Acta, 56, 9860-9867.

[9] E.Castado Rivera, D. J.Volpe, L.Alden, C.Lind, C. Downie, T.Vazkez Alvarez, A.C.D.Angelo, F.J. DiSalvo, H. D. Abruna (2004) Electrocatalytic activity of Ordered Intermetallic Phases for Fuel Cell Applications, J. Am. Chem. Soc., 126, 4043-4049.

[10] F.Matsumoto, C.Roychowdhury, F.J.Disalvo, $H$. D.Abruna (2008) Electrocatalytic Activity of Ordered Intermetallic PtPb Nanoparticles Prepared by Borohydride Reduction toward Formic Acid Oxidation, J. Electrochem. Soc., 155, 148-154.

[11] J.B.Xu, T.S.Zhao, Z.X.Liang (2008) Carbon supported platinum-gold alloy catalyst for direct formic acid fuel cells, J. Power Sources, 185, 857861.

[12] Y.C.Bai, W.D.Zhang, C.H.Chen, J.Q.Zhang (2011) Carbon nanotubes-supported Pt-Aualloy nanoparticles for electro-oxidation of formic acid with remarkable activity, Journal of Alloys and Compounds, 509, 1029-1034.

[13] Y. Li, S. Wu, X. Cui, L. wang, X. Shi (2012) Ultralow platinum-loading bimetallic nanoflowers: Fabrication and high-performance electrocatalytic activity towards the oxidation of formic acid, Electrochem. Comm., 25, 19-22.

[14] M.D.Obradovic, J.R.Rogan, B.M.Bobic, A.V. Tripkovic, A.R.S.Goutam, V.R.Radmilovic, S.Lj. Gojkovic (2012) Formic acid oxidation on Pt-Au nanoparticles: Relation between the catalyst activity and the poisoning rate, J. Power Sorces, 197, 7279.

[15] M.D.Obradovic, A.V.Tripkovic, S.Lj.Gojkovic (2009) The origin of high activity of Pt-Au surfaces in the formic acid oxidation, Electrochim. Acta, 55, 204209.
[16] R.Jiang, S.Tung, Z.Tang, L.Lei, L.Ding, X.Xi, Y.Liu, L.Zhang, J.Zhang (2018) A review of core-shell nanostructured electrocatalysts for oxygen reduction reaction, Energy Storage Mater., 12, 260276.

[17] R.A.Martinez- Rodrigez, F.T. Vidal-Iglesias, J. SollaGullon, C. R. Cabrera, J. M. Feliu (2014) Synthesis of $\mathrm{Pt}$ nanoparticles in water- in-oil microemulsion: effect of $\mathrm{HCl}$ on their surface structure, J Am Chem Soc, 136, 1280-1283.

[18] A.Ferre-Vilaplana, J.Perales-Rondon, J.M.Feliu, E. Herrero (2015) Understanding the effect of the adatoms in the formic acid oxidation mechanism on Pt(111) electrodes, ACS Catalysis, 5, 645-654.

[19] M.N.Krstajic Pajic, S.I.Stevanovic, V.V.Radmilovic, A.Gavrilovic-Wohlmuther, V. R. Radmilovic, S.Lj. Gojkovic, V.M.Jovanovic (2016) Shape evolution of carbon supported Pt nanoparticles: From synthesis to application, App. Catalysis B: Enviromental, 196, 174-184.

[20] TOPAS V2. General Profile and Structure Analysis Software for Powder Diffraction Data (2003) User Manual, Bruker AXS, Karlsruhe, Germany

[21] I.S.Park, K.-S. Lee, J.H.Choi, H. Y. Park, Y.E.Sung (2007) Surface Structure of Pt-Modified Au Nanoparticles and Electrocatalytic Activity in Formic Acid Electro-Oxidation, J. Phys. Chem. C, 111, 19126-19133.

[22] P.Urchaga, S.Baranton, C.Coutanceau, G. Jerkiewicz (2012) Electro-oxidation of $\mathrm{CO}_{\text {chem }}$ on $\mathrm{Pt}$ Nanosurfaces: Solution of the Peak Multiplicity Puzzle, Langmuir, 28, 3658-3663.

[23] G.Chen, Y.Li, D.Wang, L.Zheng, G.You, C.-J. Zhong, L.Yang, F.Cai, J.Cai, B.H.Chen (2011) Carbon-supported PtAu alloy nanoparticle catalysts for enhanced electrocatalytic oxidation of formic acid, J. Power Sources, 196, 8323-8330.

[24] Y.Ma, H.Zhang, H.Zhong, T.Xu, H.Jin, X.Geng (2010) High active PtAu/C catalyst with core-shell structure for oxygen reduction reaction, Catalyst Communications, 11, 434-437.

[25] A.Hamelin (1996) Cyclic voltammetry at gold singlecrystal surfaces. Part . Behavior at low-inex faces, J. Electroanal. Chem., 407, 1-11.

[26] G. Cabelloa, R.A.Davoglioa, F.W.Hartl, J.F.Marco, E.C.Pereira, S.R. Biaggio, H.Varela, A.Cuesta (2017) Microwave-Assisted Synthesis of Pt-Au Nanoparticles with Enhanced Electrocatalytic Activity for the Oxidation of Formic Acid, Electrochim. Acta, 224, 56-63.

[27] A.Lopez-Cudero, F.J.Vidal-Iglesias, J.Solla-Gullon, E. Herreo, A. Aldaz, J.M. Feliu (2009) Formic acid electrooxidation on Bi-modified $\mathrm{Pt}(110)$ single crystal electrodes, J. Electroanal. Chem., 637, 6369. 


\section{IZVOD}

\section{PtAu KATALIZATOR SA POBOLJŠANOM AKTIVNOŠĆU ZA REAKCIJU OKSIDACIJE MRAVLJE KISELINE}

PtAu sistemi se smatraju veoma dobrim katalizatorima za elektrooksidaciju mravlje kiseline, kao moguće anodne reakcije u niskotemperaturnim gorivnim galvanskim spregovima. U ovom radu bimetalne PtAu nanočestice sintetizovane su mikromulzionim postupkom, i u toku sinteze nanete na ugljenični nosač Vulcan XC-72R. Procesi redukcije prekursora odigravaju se simultano, unutar vodene faze iste mikroemulzije, u prisustvu $35 \% \mathrm{HCl}$. Elektrohemijske karakteristike katalizatora ispitivane su cikličnom voltametrijomv na "as prepared" elektrodama u $0.5 \mathrm{M} \mathrm{H}_{2} \mathrm{SO}_{4}$ kao osnovnom elektrolitu, kao i prilikom oksidacije adsorbovanog CO. Rezultati su upoređeni sa Pt/C katalizatorom sintetizovanim istim postupkom i pod istovetnim uslovima. Pripremljeni PtAu/C prah okarakterisan je takođe difrakcijom X-zraka, transmisionom elektronskom mikroskopijom i energetski disperzionom spektroskoijom. Veličina čestice određena analizom difraktograma Xzraka iznosi $2 \mathrm{~nm}$, što je blisko vrednosti dobijenoj analizom TEM snimaka od $2.82 \mathrm{~nm}$. U poređenju sa Pt nanočesticama sintetizovanim na isti način, bimetalne nanočestice su znatno manjeg prečnika. Mape uzorka PtAu/C dobijene energetski disperzionom spektroskopijom potvrđuju prisustvo oba elementa i pokazuju veoma finu distribuciju Au u uzorku. Analizo mapa utvrđeno je i da je katalizator sastava 20\% Au i 80\% Pt. Konačno, ispitane su aktivnost i stabilnost bimetalnog katalizatora za oksidaciju mravlje kiseline. Snimljeni voltamogrami ukazuju na promenu reakcionog mehanizma i bolje iskorišćenje površine katalizatora u poređenju ra Pt/C katalizatorom sintetizovanim istim postupkom.

Ključne reči: PtAu nanočestice, mikroemulziona metoda, oksidacija mravlje kiseline.

Naučni rad

Rad primljen: 26.04. 2018.

Rad prihvaćen: 14. 05. 2018.

Rad je dostupan na sajtu: www.idk.org.rs/casopis

(c) 2018 Authors. Published by Engineering Society for Corrosion. This article is an open access article distributed under the terms and conditions of the Creative Commons Attribution 4.0 International license (https://creativecommons.org/licenses/by/4.0/) 